ISSN 1392-3196 / e-ISSN 2335-8947

Zemdirbyste-Agriculture, vol. 101, No. 2 (2014), p. 177-184

DOI 10.13080/z-a.2014.101.023

\title{
Sensitivity of Mycosphaerella graminicola isolates to demethylation-inhibiting (DMI) fungicides
}

\author{
Antanas RONIS ${ }^{1}$, Lise Nistrup JØRGENSEN ${ }^{2}$, Roma SEMAŠKIENE ${ }^{1}$, \\ Irena GAURILČIKIENE ${ }^{1}$, Jūratè RAMANAUSKIENE ${ }^{1}$ \\ ${ }^{1}$ Institute of Agriculture, Lithuanian Research Centre for Agriculture and Forestry \\ Instituto 1, Akademija, Kedainiai distr., Lithuania \\ E-mail: antanasr@1zi.lt_ \\ ${ }^{2}$ Aarhus University \\ Forsøgsvej 1, 4200 Slagelse, Denmark
}

\begin{abstract}
Mycosphaerella graminicola (Fuckel) J. Schröt. (anamorph Zymoseptoria tritici (Desm.) Quaedvlieg \& Crous) causes Septoria leaf blotch disease of wheat. The disease can be responsible for yield losses of $30-50 \%$ and, when severe, requires management with a fungicide. Single picnidia isolates collected from different locations of Lithuania were tested in vitro for sensitivity to demethylation-inhibiting (DMI) fungicides epoxiconazole, cyproconazole and prothioconazole. Fungicide concentrations were chosen from the proposed Fungicide Resistance Action Committee (FRAC) methods. Microtitre plates with 96-wells were inoculated with suspensions of pycnidiospores taken from single pycnidia of leaves. In total, 196 isolates from 34 locations were tested over the three experimental years (2009-2011). The results showed reduced sensitivity of M. graminicola isolates to epoxiconazole and cyproconazole. The average $\mathrm{EC}_{50}$ values over three experimental years for epoxiconazole varied between 1.02 and $3.15 \mathrm{mg} \mathrm{l}^{-1}$, for cyproconazole -1.51 and $10.66 \mathrm{mg} \mathrm{l}^{-1}$. The sensitivity to prothioconazole of 64 isolates from 13 locations (2011) ranged from 0.43 to $32.28 \mathrm{mg} \mathrm{l}^{-1}$. Results of field experiments (20072011) showed that fungicides epoxiconazole and prothioconazole significantly reduced the area under the disease progress curve (AUDPC) values of Septoria leaf blotch compared with untreated plots in winter wheat. In most cases, a single fungicide application significantly increased grain yield and a thousand grain weight weight.
\end{abstract}

Key words: AUDPC, cyproconazole, epoxiconazole, Mycosphaerella graminicola, prothioconazole, sensitivity, winter wheat.

\section{Introduction}

Septoria leaf blotch caused by Mycosphaerella graminicola (Fuckel) J. Schröt. (anamorph Zymoseptoria tritici (Desm.) Quaedvlieg \& Crous) is one of the most common foliar fungal pathogens of wheat, causing considerable losses of yield and quality in North Europe and elsewhere. Yield losses caused by this pathogen were reported up to $60 \%$ (Mavroeidi, Shaw, 2005). In Denmark, after fungicide application grain yield increase in highly septoria-susceptible varieties was 2.0-3.0 t ha $\mathrm{t}^{-1}$ and about 1.0-1.5 t ha $\mathrm{t}^{-1}$ in more resistant varieties (Jørgensen et al., 2000).

A complex of leaf diseases usually occurred in winter and spring wheat in Lithuania. M. graminicola appears in a Septoria disease complex with Phaeosphaeria nodorum (E. Müller) Hedjaroude (anamorph Stagonospora nodorum [Berk.] Castellani \& E.G. Germano). Also, another important leaf spotting disease is tan spot, caused by Pyrenophora tritici-repentis (Died.)
Drechs. (anamorph Drechslera tritici-repentis (Died.) Shoem.). It is estimated that these leaf diseases might reduce grain yield from $3.7 \%$ to $25.4 \%$ but in some cases possible yield losses could be up to $49.0 \%$ (Butkute et al., 2008). Control methods such as tillage, crop rotation, late sowing dates, or growing resistant cultivars are almost ineffective or contribute only marginally to the solution of the problem caused by the disease (Gladders et al., 2001). Commercially available cultivars with acceptable agronomic performance do not have adequate resistance to fungal diseases (Liatukas et al., 2012). Consequently, the current control strategies rely mainly on fungicide application. Fungicides have contributed significantly to steady improvements in yield and quality of agricultural products (Jørgensen, 2008). One of the major risks associated with intensive use of fungicides over large areas is the potential for partial or total loss of efficacy due to the emergence of pathogen phenotypes that have 
the ability to overcome the activity of the fungicides (Fraaije et al., 2003; Gisi et al., 2005; Jørgensen, 2008). The degree of risk associated with resistance to a fungicide is dependent on its mode of action, the way it is used and the evolutionary potential of the target fungi (Birch, Shaw, 1997; Shaw, 2000). Azoles epoxiconazole, cyproconazole and prothioconazole belong to the group of demethylation inhibitors (DMIs). Their mode of action is the inhibition of the demethylation at the 14- $\alpha$ carbon of lanosterol or 24-methylene dihydrolanosterol. The latter two compounds are substrates for the cytochrome P450-dependent 14- $\alpha$ demethylase in the biosynthesis of fungal sterols (Gisi et al., 2005). The gene coding for the 14- $\alpha$ demethylase was termed CYP51 or ERG11, and several point mutations were associated with a gradual loss of sensitivity of fungi towards DMIs (Leroux et al., 2007). Furthermore, experimental evidence suggests that ABC (ATP-binding casette) - transporters located in the outer membrane of fungal cells is involved in fungicide resistance of $M$. graminicola by exporting the toxic compounds (Stergiopoulos et al., 2003). DMIs were first introduced in the 1970s: prochloraz in 1977, propiconzole in 1979, tebuconazole in 1986, epoxiconazole in 1990 and prothioconazole in 2002 (Russell, 2005).

There are many reports that performance of DMIs is declining in many European countries which is due to mutations and mutation combinations in CYP51. High efficacy of DMIs on Septoria leaf blotch is also an essential resistance-management tool for the new succinate dehydrogenase inhibitor fungicides, which are currently classified as compound with a moderate to high resistance risk (Fungicide Listing by FRAC Code, 2013).

The overall purpose of the work reported here was to determine the sensitivity of $M$. graminicola to DMI group fungicides (epoxiconazole, cyproconazole and prothioconazole), to determine the recent trend in sensitivity of $M$. graminicola to these fungicides under Lithuanian conditions and finally to assess their $\mathrm{EC}_{50}$ mean values.

\section{Materials and methods}

Leaf sampling. In commercial winter and spring wheat fields at different places of Lithuania, 30-50 flag leaves of wheat were collected at GS 73-75 growth stages. Every year the number of visited sites varied from 18 to 20; however, not in all sites disease symptoms were present. Locations, where wheat leaf samples with Mycosphaerella graminicola symptoms were collected are presented in Table 1. Each site was approximately 50-80 km apart from one another. Leaf samples were dried and frozen until the start of the experiment.

Table 1. The origin of Mycosphaerella graminicola isolates tested in the experiment

\begin{tabular}{|c|c|}
\hline Year & Origin of isolates \\
\hline 2009 & Jurbarkas (4*), Kupiškis (8), Trakai (5), Vilkaviškis (3) \\
\hline 2010 & $\begin{array}{l}\text { Jonava (2), Joniškis (12), Jurbarkas (12), Kalvarija (2), Kelmė (5), Kėdainiai (10), Lazdijai (5), Marijampolè (4), } \\
\text { Pasvalys (7), Prienai (4), Radviliškis (7), Ramygala (8), Rokiškis (2), Šakiai (10), Šiauliai (8), Tauragè (7), Ukmergè (7) }\end{array}$ \\
\hline 2011 & $\begin{array}{l}\text { Alytus (6), Anykščiai (6), Baisogala (6), Jonava (4), Joniškis (6), Jurbarkas (6), Kaišiadorys (6), Maišiagala (6), } \\
\text { Prienai (6), Raseiniai (2), Šakiai (2), Šiauliai (6), Upytė (2) }\end{array}$ \\
\hline
\end{tabular}

* - in brackets, the number of isolates tested in the experiment

Spore production and isolation. At the beginning of the experiment wheat leaves were defrosted and cut into $2 \mathrm{~cm}$ pieces. Wheat leaves were surface-sterilized for 5-10 seconds in a $75.0 \%$ ethyl ethanol solution and then rinsed in sterile distilled water and put in Petri dishes containing 2 layers of filter paper (grade 1) moistened with $1.5 \mathrm{ml}$ sterile distilled water. It took about 18-22 hours for cirri to become large enough to be removed. The shorter this incubation was, the lower the risk of contamination. From each leaf, a random cirrus was picked off under a binocular microscope using a sterile needle and placed in Petri dishes with V-8 Juice agar amended with $\mathrm{CaCO}_{3}$ at $3 \mathrm{~g} \mathrm{l}^{-1}$ ("Carl Roth GmbH+Co", Germany), Bacto agar at $20 \mathrm{~g} \mathrm{l}^{-1}$ ("Liofilchem", Italy), streptomycin at $100 \mathrm{mg} \mathrm{l}^{-1}$ ("AppliChem GmbH", Germany) and rifampicin at 100 $\mathrm{mg} \mathrm{l}^{-1}$ ("AppliChem GmbH"). Antibiotic streptomycin was dissolved in $1 \mathrm{ml}$ of ethanol and antibiotic rifampicin
- in $5 \mathrm{ml}$ before adding to the medium. The medium was cooled down to $45^{\circ} \mathrm{C}$ before adding antibiotics. To obtain pure cultures, isolates were sub-cultured on agar without antibiotics from single colonies. The final number of extracted isolates varied from 2 to 12 due to lack of disease symptoms or contamination by other pathogens.

Fungicide sensitivity testing. Assays were performed in clear, sterile flat-bottom polystyrene microtiter plates with 96-wells ("Nunc A/C", Denmark). Potato dextrose agar amended with yeast extract at $5 \mathrm{~g} \mathrm{l}^{-1}$ and at different concentrations of fungicides (Dr. Ehrenstorfer $\mathrm{GmbH}$, Germany) was used as growth medium. Necessary amounts of fungicides were scaled, diluted in acetone and sterile distilled water. Initial concentration was calculated at $100 \%$ of pure amount of active substance. The final concentration ranges of fungicides tested are given in Table 2. Aliquots of $30 \mu \mathrm{l}$ of spore suspensions (an average 
of 75000 spores $\mathrm{ml}^{-1}$ ) were added to $270 \mu \mathrm{l}$ of growth medium in each well. After 6-7 days of incubation at $20^{\circ} \mathrm{C}$, growth was visually estimated relative to control, by designating into $5 \%$ intervals, and $50 \%$ effective concentration $\left(\mathrm{EC}_{50}\right)$ values were calculated using a doseresponse relationship. Initially fungicides epoxyconazole and cyproconazole were used in the sensitivity tests. In Denmark, since 2010 there has been observed a steep shift in fungicide prothioconazole sensitivity. In 2009, average $\mathrm{EC}_{50}$ value for fungicide prothioconazole was $0.7 \mathrm{mg}$ $\mathrm{l}^{-1}$ while in the following year it increased to $4.4 \mathrm{mg} \mathrm{l}^{-1}$. Therefore, in 2011, it was decided to extend the trials by including fungicide prothioconazole.

Table 2. Fungicides and their final concentration used in the experiment (Monitoring methods, 2006)

\begin{tabular}{ccccccccc}
\hline Fungicides & \multicolumn{7}{c}{ Concentration ppm } \\
\hline Epoxiconazole & 3 & 1.1 & 0.37 & 0.12 & 0.04 & 0.013 & 0 \\
& & & & & & \\
Cyproconazole & 10 & 3 & 1.1 & 0.37 & 0.12 & 0.04 & 0 \\
Prothioconazole & 30 & 10 & 3 & 1.1 & 0.37 & 0.12 & 0 \\
\hline
\end{tabular}

Field experiments. Field trials were established in 2007-2011 at Institute of Agriculture, Lithuanian Research Centre for Agriculture and Forestry. Winter wheat crop was not additionally inoculated by Mycosphaerella graminicola spores, Septoria leaf blotch occurred and spread within the crop naturally. Winter wheat cv. 'Zentos' was grown in 2007-2009 and 2011, cv. 'Aperitif' in 2009 and cvs 'Mulan' and 'Kovas' in 2010. Fungicide applications were started at the booting stage (GS 41-45), except for the year 2009, when fungicides were applied at the beginning of ear emergence stage (GS 51). Fungicide Opus (a.i. epoxyconazole, $125 \mathrm{~g} \mathrm{l}^{-1}$, BASF A/S) was used from 2007 to 2011, while fungicide Proline (a.i. prothioconazole, $250 \mathrm{~g} \mathrm{l}^{-1}$, "Bayer Crop Science") was used only in 2009 and 2011. The first disease assessments were done prior to fungicide application, others - at 10 days' intervals until senescence of wheat leaf (GS 79-83). Three top leaves were scored for percent of leaf area covered by Septoria leaf blotch symptoms. The diseased area was visually assessed on 10 randomly selected main tillers per plot. The area under disease progress curves (AUDPC) was calculated using the percent estimates ratings (Introduction..., 1990).

Statistical analysis. The sensitivity level for each isolate was determined as half maximal inhibitory concentration $\left(\mathrm{EC}_{50}\right)$ value calculated from the corresponding dose-response curve using the software GraphPadPrism5 whose free demo version was acquired from the company's web page ("GraphPad Software Inc.”, USA). Mean $\mathrm{EC}_{50}$ values were calculated for each combination of fungicide and different site for every year separately. Comparisons of means for growth in dose- response curves were performed with the ANOVA test at significance level $P<0.05$ using the software $A N O V A$. Then these results were used to find the differences between years which were measured with the Duncan's multiple range test using the software package ANOVA. Duncan's multiple range test was also used to establish the differences between untreated and fungicide-treated plots in field experiments (Tarakanovas, Raudonius, 2003).

\section{Results}

In vitro test. Performing analysis with DMI fungicide epoxiconazole it was determined that peak frequency of $\mathrm{EC}_{50}$ values in 2009 was at $2.5 \mathrm{mg} \mathrm{l}^{-1}$ with $45.0 \%$ of all tested population (Fig.). The following year, peak frequency was reached at $2.0 \mathrm{mg} \mathrm{l}^{-1}$ and percentage of population was very close to previous year (44.6\%). In 2011 , the peak frequency $\mathrm{EC}_{50}$ values were determined at $2.0 \mathrm{mg} \mathrm{l}^{-1}$ with over $85.0 \%$ of tested isolates. The results of resistance to fungicide cyproconazole show that peak frequency of $\mathrm{EC}_{50}$ values consistently grew each year. In 2009 , the peak frequency of $\mathrm{EC}_{50}$ values was at $3.0 \mathrm{mg} \mathrm{l}^{-1}$ with $57.5 \%$ of all tested isolates. The following year, the average $\mathrm{EC}_{50}$ value for $80.3 \%$ of all tested isolates was $6.0 \mathrm{mg} \mathrm{l}^{-1}$. In 2011, the peak frequency of $\mathrm{EC}_{50}$ values was at the same level as previous year for $67.2 \%$ of tested isolates. Also it was found that the average $\mathrm{EC}_{50}$ values for $20.3 \%$ is $9.0 \mathrm{mg} \mathrm{l}^{-1}$ and for $9.4 \%-12.0 \mathrm{mg} \mathrm{l}^{-1}$. Since 2011, fungicide prothioconazole was included in the trial series. $\mathrm{EC}_{50}$ values for this fungicide ranged from 0.43 to $32.28 \mathrm{mg} \mathrm{l}^{-1}$. Nearly half (46.9\%) of all tested isolates had $\mathrm{EC}_{50}$ values at the interval from 3.0 to $10.0 \mathrm{mg} \mathrm{l}^{-1}$.

The mean epoxiconazole $\mathrm{EC}_{50}$ values of isolates collected in 2009 and 2010 did not differ significantly; however, in 2011, mean $\mathrm{EC}_{50}$ values significantly increased compared with those in previous years (Table 3). Mean cyproconazole $\mathrm{EC}_{50}$ values increased every year and significant differences were determined between each year. Fungicide prothioconazole was included in the experiment in 2011. The mean $\mathrm{EC}_{50}$ value was $8.77 \mathrm{mg} \mathrm{l}^{-1}$.

Table 3. Comparison of mean effective demethylationinhibiting (DMI) fungicide concentrations that inhibited Mycosphaerella graminicola growth by $50 \%\left(\mathrm{EC}_{50} \mathrm{mg} \mathrm{l}^{-1}\right)$ for isolates collected in 2009-2011

\begin{tabular}{cccc}
\hline Group & Epoxiconazole & Cyproconazole & Prothioconazole \\
\hline $2009(\mathrm{n}=20)$ & $1.73 \mathrm{a}$ & $3.37 \mathrm{a}$ & n.a \\
$2010(\mathrm{n}=112)$ & $1.77 \mathrm{a}$ & $5.20 \mathrm{~b}$ & n.a \\
$2011(\mathrm{n}=64)$ & $2.10 \mathrm{~b}$ & $6.66 \mathrm{c}$ & 8.77 \\
\hline
\end{tabular}

Note. Means within a column fallowed by the same letter are not significantly different according to Duncan's multiple range test at $P<0.01$ probability level; n.a. - not assessed. 

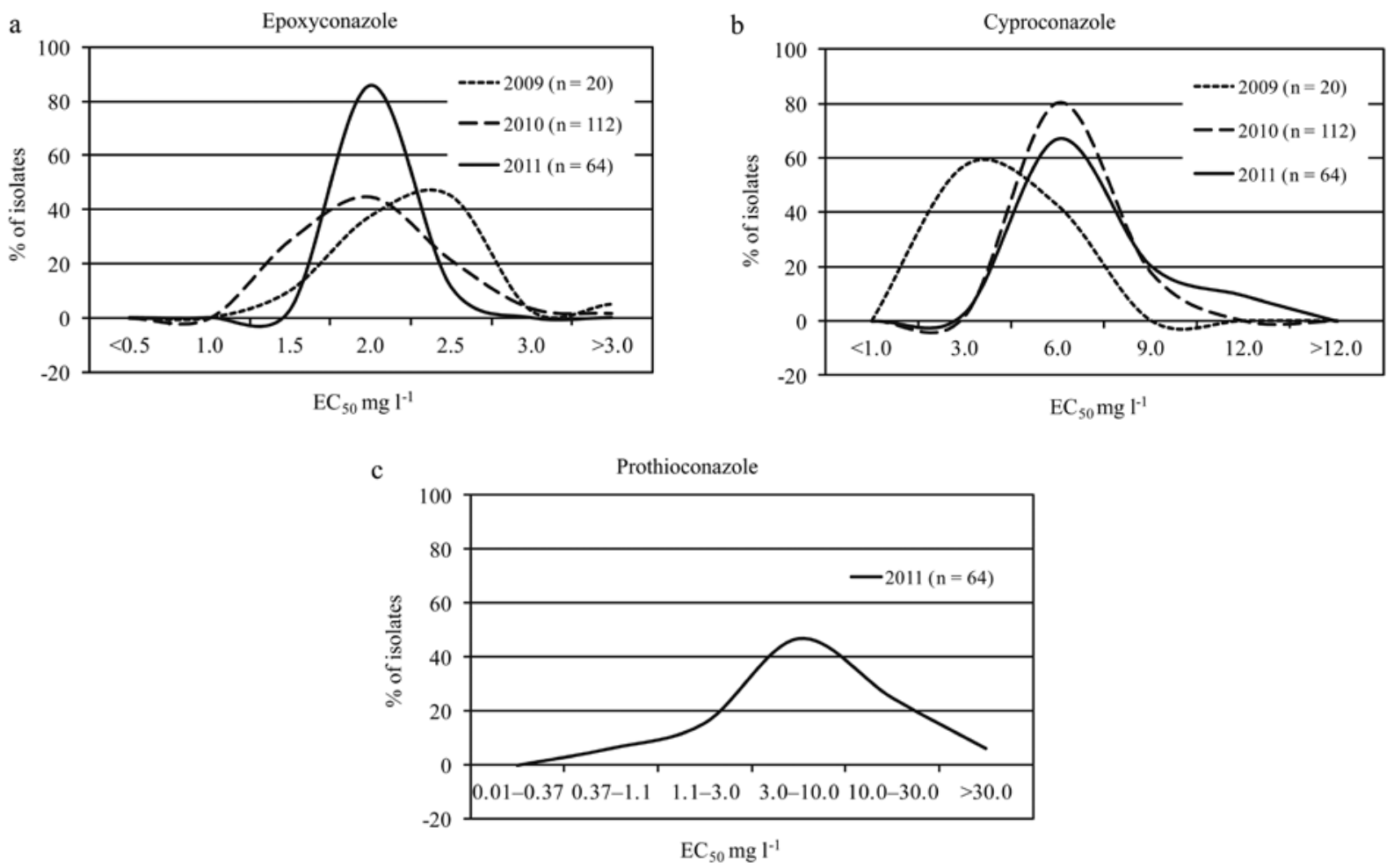

Figure. Percentage distribution of the Mycosphaerella graminicola isolates in the level of tolerance to fungicides epoxiconazole (a), cyproconazole (b) over 2009-2011 years and prothioconazole (c) over 2011 year

Field experiments. The severity of Septoria leaf blotch disease in winter wheat crops was very uneven over all experimental years mainly due to the different meteorological conditions. Average AUDPC values varied from 40.08 to 969.37 (Table 4). Fungicide epoxyconazole gave a significant disease control over all experimental years, except in 2009 in cv. 'Zentos'. In 2007, epoxyconazole reduced disease AUDPC values by nearly 15 times compared with untreated control. In the following year (2008), the values were reduced by nearly 4 times, while later epoxyconazole managed to reduce disease severity only by about 2 times.

In all years, except for 2011, significant yield increase was obtained (Table 5). A single epoxyconazole application increased grain yield from 0.31 to $1.77 \mathrm{t} \mathrm{ha}^{-1}$. Also, a significant thousand grain weight increase was observed in all years, too. An increase of thousand grain
Table 4. Area under disease progress curve (AUDPC) of winter wheat (leaves 1-3) infected by Mycosphaerella graminicola following single application of epoxyconazole and prothioconazole or left untreated over 2007 to 2011

\begin{tabular}{cccc}
\hline \multirow{2}{*}{ Year / cultivar } & \multicolumn{3}{c}{ AUDPC } \\
\cline { 2 - 4 } & Untreated & Epoxyconazole & Prothioconazole \\
\hline 2007 / 'Zentos' & $228.38 \mathrm{~b}$ & $14.64 \mathrm{a}$ & n.a. \\
2008 / 'Zentos' & $174.13 \mathrm{~b}$ & $39.21 \mathrm{a}$ & n.a. \\
2009 / 'Zentos' & $540.42 \mathrm{c}$ & $325.05 \mathrm{abc}$ & $413.46 \mathrm{a}$ \\
2009 / 'Aperitif', & $446.48 \mathrm{~b}$ & $225.77 \mathrm{a}$ & $208.20 \mathrm{a}$ \\
2010 / 'Mulan' & $959.61 \mathrm{~b}$ & $727.67 \mathrm{a}$ & n.a. \\
2010 / 'Kovas' & $969.37 \mathrm{~b}$ & $565.0 \mathrm{a}$ & n.a. \\
2011 / 'Zentos' & $40.08 \mathrm{~b}$ & $16.19 \mathrm{a}$ & $25.10 \mathrm{a}$ \\
\hline
\end{tabular}

Note. Means within a line followed by the same letter are not significantly different according to Duncan's multiply range test at $P<0.01$ probability level; n.a. - not assessed.

Table 5. Effect of fungicides epoxyconazole and prothioconazole on grain yield and thousand grain weight (TGW) in winter wheat over 2007 to 2011

\begin{tabular}{ccccccc}
\hline \multirow{2}{*}{ Year / cultivar } & \multicolumn{3}{c}{ Yield t ha $^{-1}$} \\
\cline { 2 - 7 } & Untreated & Epoxyconazole & Prothioconazole & Untreated & Epoxycoazole & Prothioconazole \\
\hline 2007 / 'Zentos' & $6.89 \mathrm{a}$ & $8.18 \mathrm{~b}$ & n.a. & $44.03 \mathrm{a}$ & $49.34 \mathrm{~b}$ & n.a. \\
2008 / 'Zentos' & $8.94 \mathrm{a}$ & $9.25 \mathrm{~b}$ & n.a. & $47.43 \mathrm{a}$ & $48.13 \mathrm{~b}$ & n.a. \\
2009 / 'Zentos' & $8.20 \mathrm{a}$ & $8.96 \mathrm{c}$ & $9.03 \mathrm{c}$ & n.a. & n.a. & n.a. \\
2009 / 'Aperitif' & $6.73 \mathrm{a}$ & $7.45 \mathrm{c}$ & $7.67 \mathrm{c}$ & n.a. & n.a. & n.a. \\
2010 / 'Mulan' & $5.17 \mathrm{a}$ & $6.94 \mathrm{~b}$ & n.a. & $35.98 \mathrm{a}$ & $41.86 \mathrm{~b}$ & n.a. \\
2010 / 'Kovas' & $3.84 \mathrm{a}$ & $4.60 \mathrm{~b}$ & n.a. & $36.21 \mathrm{a}$ & $40.69 \mathrm{~b}$ & n.a. \\
2011 / 'Zentos' & $6.61 \mathrm{ab}$ & $6.56 \mathrm{ab}$ & $6.83 \mathrm{~b}$ & $42.56 \mathrm{a}$ & $44.35 \mathrm{c}$ & $44.67 \mathrm{c}$ \\
\hline
\end{tabular}

Explanations under Table 4 
weight was from 0.70 to $5.88 \mathrm{~g}$ compared with the grain weight from untreated plots. Fungicide prothioconazole in 2009 experimental year was tested in cvs 'Zentos' and 'Aperitif', while in 2009 - only in cv. 'Zentos'. In all cases, fungicide gave a significant disease control compared with untreated control. In the plots where prothioconazole was applied, Septoria leaf blotch AUDPC values were lower by 1.3-2 times compared with untreated control. A single prothioconazole application significantly increased grain yield by $0.22-0.94 \mathrm{t} \mathrm{ha}^{-1}$.

\section{Discussion}

DMI fungicides have been dominating the European market for about forty years. DMIs represent one of the largest groups of systemic fungicides that have been used to control agriculturally important fungal pathogens (Zhan et al., 2006). In Lithuania, the first DMI fungicide propiconazole (trade name Tilt) was investigated and introduced in the market in mid 1980s for control of winter wheat diseases (Gaurilčikienè et al., 2010). Currently about 10 DMIs are registered as solo products or in commercial mixtures for cereal disease control. Despite long-term use of DMIs, only minor changes in the sensitivity of $M$. graminicola populations to DMIs in European countries were reported up until 1994 (Turner et al., 1996). During the last 10 years, numerous studies in many countries have been done to determine the sensitivity of $M$. graminicola to fungicides (Dutzmann, Suty-Heinze, 2004; Stammler, Semar, 2011). The results presented in this paper are the first scientific attempt to determine the sensitivity of $M$. graminicola to DMI fungicides in Lithuania.

Epoxiconazole was introduced to the market by BASF SE in 1990 and its active substance can be found in many products and product mixtures targeting main pathogens in cereals (Morton, Staub, 2008). In Lithuania, epoxiconazole for the first time was registered in commercial mixture (Tango super) with fenpropimorph in 1998. Single epoxiconazole for commercial use has been approved in Lithuania since 2001. Epoxiconazole and prothioconazole have generally been seen to be highly efficient against $M$. graminicola, but in recent years the decline in the effectiveness was recorded in some countries (Cools et al., 2011).

In our study, the average $\mathrm{EC}_{50}$ values over three experimental years for epoxiconazole varied between 1.02 and 3.15 ppm. Stammler and Semar (2011) after testing $M$. graminicola isolates, collected across European countries, determined that the sensitivity ranged from values of 0.003 to nearly $1 \mathrm{ppm}$ in 2006 2008. Similar results were obtained by Danish scientists (Jørgensen etal., 2012). They determined that over period from 2005 to 2007 a peak frequency of sensitive M. graminicola isolates to epoxiconazole varied from 0.1 to $1.0 \mathrm{ppm}$. A slight shifting was observed in 2008 , when peak frequency increased from 0.33 to $3.33 \mathrm{ppm}$.
Triazole fungicide cyproconazole was introduced by "Sandoz Agro" (now "Syngenta Crop Protection") in 1982 (Anonymous, 1997). The fungicide has been used for many years to control M. graminicola and other pathogens (Gisi et al., 1997). Single cyproconazole as fungicide Alto was used for 7 years' period in Lithuania - from 1993 till 2000. Commercial mixtures of cyproconazole with triazole propiconazole (since 2000 - Artea) and strobilurine azoxystrobin (since 2004 -Amistar xtra) are available on the market today. In our study, we found that the average $\mathrm{EC}_{50}$ values varied from 1.51 to $10.66 \mathrm{ppm}$. Studies by other researchers revealed a wide variation in baseline sensitivity to the fungicide cyproconazole among the isolates of $M$. graminicola sampled from the same countries. Gisi et al. (1997) assayed nearly 1000 M. graminicola isolates from several European countries for their baseline sensitivity to cyproconazole. They found nearly 5 to 40 -fold differences in sensitivity among the isolates collected from the same countries. Also, Stergiopoulos et al. (2003) after testing of 20 isolates from France and Germany found that minimum inhibitory concentration varied from 0.056 to $100 \mathrm{ppm}$. This is nearly 2000-fold difference in baseline sensitivity among the isolates.

The fungicide prothioconazole was introduced to the European market in 2002 and is widely used to control M. graminicola and other pathogens in cereals (Dutzmann, Suty-Heinze, 2004; Sanssene et al., 2011). Prothioconazole has been sold in commercial mixtures with tebuconazole (Prosaro) and spiroxamine (Input) in Lithuania since 2006. Mixtures of prothioconazole with the strobilurine fluoxastrobin (Fandango) and tebuconazole and spiroxamine (Falcon Forte) have been introduced to market since 2009 and 2010, respectively. Single prothioconazole has not been approved in Lithuania. Since the introduction of prothioconazole, this active substance has shown very good efficacy for control M. graminicola in many countries (Dutzmann, Suty-Heinze, 2004). But Cools et al. (2011) determined that recently emerged mutations of the MgCYP51 protein confer reduced in vitro sensitivity to this active substance. During one year of investigation of isolates from Latvia, it was determined that the average $\mathrm{EC}_{50}$ value varies from 0.43 to $32.28 \mathrm{ppm}$. A few wheat leaf samples were sent to Denmark where $M$. graminicola isolates were extracted for NORBARAG trials. During that study, it was determined that isolates from Lithuania and from neighbouring Latvia had average $\mathrm{EC}_{50}$ value 16 ppm for prothioconazole (Jørgensen et al., 2012). In Denmark, sensitivity towards prothioconazole reduced noticeably from 2009 to 2011 . In 2009 , about $55.0 \%$ of all isolates had peak frequency from 0.33 to $1.0 \mathrm{ppm}$. In 2010 , for about $30 \%$ of isolates peak frequency increased from 3.33 to $10.0 \mathrm{ppm}$. During the last year about half of the tested isolates had peak frequency from 10.0 to 30.0 ppm (Jørgensen et al., 2012). 
Although in vitro test shows reduced sensitivity of $M$. graminicola isolates to the azoles, the products with these active substances still provided effective control of Septoria leaf blotch under field conditions (Tvaružek et al., 2005). Other scientists suggest that there is no correlation or correlation is very low between the efficacies of fungicides under field conditions and laboratory tests. Primarily, because factors such as application timing, weather conditions and disease pressure may influence fungicide efficacy (Stammler et al., 2008). There is a common agreement that a low number of fungicide resistant strains already exist before the introduction of a new fungicide. The frequency of resistance genotypes will increase under the selection pressure of the fungicides, and the entire population will shift to a new equilibrium on selection pressure and fitness penalty (Köller, Scheinpflug, 1987).

It is generally expected that fungicide resistance problems can be minimized by implementing integrated plant protection measures at the state and every farm level. This implies that the disease pressure should be kept as low as possible by growing resistant cultivars or using other means to reduce disease pressure. Other important means to minimize the risk for resistance is by using active substances only once or twice per season, avoiding high rates which have been proven to trigger resistance. Also using mixtures instead of single active substances has been shown to reduce resistance and preferably the mixing partner should be broad-spectrum fungicide, which has proven to minimize the risk best.

\section{Conclusions}

1. In vitro testing of 196 Mycosphaerella graminicola isolates from 34 locations of Lithuania showed that epoxiconazole $\mathrm{EC}_{50}$ values varied from 1.02 to $3.15 \mathrm{mg} \mathrm{l}^{-1}$ with a peak frequency from 2.0 to $2.5 \mathrm{mg}$ $1^{-1}$. The $\mathrm{EC}_{50}$ values of the fungicide cyproconazole varied from 1.51 to $10.66 \mathrm{mg} \mathrm{l}^{-1}$ with a peak frequency from 3.0 to $6.0 \mathrm{mg} \mathrm{l}^{-1}$. The $\mathrm{EC}_{50}$ values of prothioconazole varied from 0.43 to $32.28 \mathrm{mg} \mathrm{l}^{-1}$ with a peak frequency from 3.0 to $10.0 \mathrm{mg} \mathrm{l}^{-1}$ for 64 isolates from 13 locations.

2. Over the period 2009-2011, a significant decline in sensitivity of the tested isolates of M. graminicola to epoxiconazole and cyproconazole occurred. Mean $\mathrm{EC}_{50}$ values increased from 1.73 to 2.10 and from 3.37 to $6.66 \mathrm{mg} \mathrm{l}^{-1}$, respectively.

3. A single application of the fungicides epoxiconazole and prothioconazole under field conditions in most cases gave a significant Septoria leaf blotch control compared with the untreated plots, which consequently gave significant grain yield increase. Epoxiconazole and prothioconazole increased grain yield by $0.31-1.77 \mathrm{t} \mathrm{ha}^{-1}$ and by $0.22-0.94 \mathrm{t} \mathrm{ha}^{-1}$, respectively.

Received 14022013

Accepted 22042014

\section{References}

Anonymous. 1997. Summary of toxicological studies on cyproconazole. Journal of Pesticide Science, 22: 263-268 http://dx.doi.org/10.1584/jpestics.22.263

Birch C. P. D., Shaw M. W. 1997. When can reduced doses and pesticide mixtures delay the build-up of pesticide resistance? A mathematical model. Journal of Applied Ecology, 34: 1032-1042 http://dx.doi.org/10.2307/2405292

Butkutė B., Paplauskienė V., Gaurilčikienè I. 2008. Efficacy of fungicide treatments on the winter wheat senescence, grain yield, protein concentration and yield. ZemdirbysteAgriculture, 95 (3): 242-250

Cools H. J, Mullins J. G. L., Fraaije B. A., Parker J. E., Kelly D. E., Lucas J. A., Kelly S. L. 2011. Impact of recently emerged sterol 14-demethylase (CYP51) variants of Mycosphaerella graminicola on azole fungicide sensitivity. Applied and Environmental Microbiology, 77 (11): 3830-3837 http://dx.doi.org/10.1128/AEM.00027-11

Dutzmann S., Suty-Heinze A. 2004. Prothioconazole: a broad spectrum demethylation-inhibitor (DMI) for arable crops. Pflanzenschutz-Nachrichten Bayer, 57 (2): 249-264

Fraaije B. A., Lucas J. A., Clark W. S., Burnett F. J. 2003. QoI resistance development in populations of cereal pathogens in the UK. Proceedings of the BCPC Congress, Crop Science and Technology. Glasgow, UK, vol. 2, p. 689-694

Fungicide Listing by FRAC Code, 2013. < http://frag.fera.defra. gov.uk/frac_table2.cfm> [accessed 1007 2013]

Gaurilčikienė I., Butkutė B., Mankevičienè A. 2010. A multiaspect comparative investigation on the use of strobilurin and triazole-based fungicides for winter wheat disease control. Carisse O. (ed.). Fungicides, p. 69-94

Gisi U., Hermann D., Ohl L., Steden C. 1997. Sensitivity profiles of Mycosphaerella graminicola and Phytophthora infestans populations to different classes of fungicides. Pesticide Science, 51: 290-298

h t t p : / / d .doi.org/ 10.1002 / ( S I C I) 1096 9063(199711)51:3<290::AID-PS637>3.0.CO;2-H

Gisi U., Pavic L., Stanger C., Hugelshofer U., Sierotzki H. 2005. Dynamics of Mycosphaerella graminicola populations in response to selection by different fungicides. Dehne H. W. et al. (eds). Modern Fungicides and Antifungal Compounds, IV, p. 89-101

Gladders P., Paveley N. D., Barrie I. A., Hardwick N. V., Hims M. J., Langton S., Taylor M. C. 2001. Agronomic and meteorological factors affecting the severity of leaf blotch caused by Mycosphaerella graminicola in commercial wheat crops in England. Annals of Applied Biology, 138 (3): 301-311

http://dx.doi.org/10.1111/j.1744-7348.2001.tb00115.x

Introduction to plant disease epidemiology. 1990. Campbell C. L., Madden L. V. (eds.). New York, USA, 532 p.

Jørgensen L. N. 2008. Resistance situation with fungicides in cereals. Zemdirbyste-Agriculture, 95 (3): 373-378

Jørgensen L. N., Henriksen K. E., Nielsen G. C. 2000. Margin over cost in disease management in winter wheat and spring barley in Denmark. Proceedings of Brighton crop protection conference. Pests and Diseases. Brighton, UK, vol. 2 , p. $655-662$ 
Jørgensen L. N., Thygesen K., Lillholt J. 2012. Data from monitoring for fungicide resistance in cereals 2011. Septoria tritici isolates' sensitivity to triazoles in Denmark, Sweden, Latvia and Lithuania. Data from NORBARAG trials. Aarhus University, Flakkebjerg, 22 p.

Köller W., Scheinpflug H. 1987. Fungal resistance to sterol biosynthesis inhibitors: a new challenge. Plant Disease, 71 (12): 1066-1074 http://dx.doi.org/10.1094/PD-71-1066

Leroux O., Albertini C., Gautier A., Gredt M., Walker A. S. 2007. Mutation in the CYP51 gene correlated with changes in sensitivity to sterol 14 a-demethylation inhibitors in field isolates of Mycosphaerella graminicola. Pest Management Science, 63: 688-698 http://dx.doi.org/10.1002/ps.1390

Liatukas Ž., Ruzgas V., Razbadauskienè K., Brazauskas G., Koppel R. 2012. Winter wheat cultivars 'Kovas DS', 'Zunda DS', 'Vikaras DS', 'Kaskada DS' for high input farming: development and characterization. ZemdirbysteAgriculture, 99 (3): 255-264

Mavroeidi V. I., Shaw M. W. 2005. Sensitivity distributions and cross-resistance patterns of Mycosphaerella graminicola to fluquinconazole, prochloraz and azoxystrobin over a period of 9 years. Crop Protection, 24: 259-266 http://dx.doi.org/10.1016/j.cropro.2004.07.014

Monitoring methods, 2006. $<$ http://www.frac.info/Monitoring Methods/anhang/SEPTTR_monitoring_method_ Syngenta_2006_V1.pdf $>$ [accessed 1007 2013]

Morton V., Staub T. 2008. A short history of fungicides. APSnet Features http://dx.doi.org/10.1094/APSnetFeature-2008-0308

Russell P. E. 2005. A century of fungicide evolution. The Journal of Agricultural Science, 143: 11-25 http://dx.doi.org/10.1017/S0021859605004971

Sanssene J., Selim S., Roisin-Fichter C., Djerroud L., Deweerb C., Halamab P. 2011. Protective and curative efficacy of prothioconazole against isolates of Mycosphaerella graminicola differing in their in vitro sensitivity to DMI fungicides. Pest Management Science, 67: $1134-1140$

Shaw M. W. 2000. Models of the effects of dose heterogeneity and escape on selection pressure for pesticide resistance. Phytopathology, 90: 333-339

http://dx.doi.org/10.1094/PHYTO.2000.90.4.333

Stammler G., Carstensen M., Koch A., Semar M., Strobel D., Schlehuber S. 2008. Frequency of different CYP51haplotypes of Mycosphaerella graminicola and their impact on epoxiconazole-sensitivity and field efficacy. Crop Protection, 27: 1448-1456 http://dx.doi.org/10.1016/j.cropro.2008.07.007

Stammler G., Semar M. 2011. Sensitivity of Mycosphaerella graminicola (anamorph: Septoria tritici) to DMI fungicides across Europe and impact on field performance. EPPO Bulletin, 41: 149-155 http://dx.doi.org/10.1111/j.1365-2338.2011.02454.x

Stergiopoulos I., Van Nistelrooy J. G. M., Kema G. H. J., De Waard M. A. 2003. Multiple mechanisms account for variation in base-line sensitivity to azole fungicides in field isolates of Mycosphaerella graminicola. Pest Management Science, 59: 1333-1343 http://dx.doi.org/10.1002/ps.766
Tarakanovas P., Raudonius S. 2003. Agronominių tyrimų duomenų statistinè analizè taikant kompiuterines programas ANOVA, STAT, SPLIT-PLOT iš paketo SELEKCIJA ir IRRISTAT. Lithuanian University of Agriculture, $58 \mathrm{p}$. (in Lithuanian)

Turner J. A., Elcock S. J., Hims M. J. 1996. Monitoring triazole fungicide sensitivity in populations of Septoria tritici. Proceedings of Brighton crop protection conference Pest and Diseases. Brighton, UK, p. 695-700

Tvaružek L. Horáková P., Ji L. 2005. Resistance behavior of Septoria tritici to some fungicides in the territory of the Czech Republic. Acta Agrobotanica, 58 (1): 79-84 http://dx.doi.org/10.5586/aa.2005.012

Zhan J., Stefanato F. L., McDonald B. A. 2006. Selection of increased cyproconazole tolerance in Mycosphaerella graminicola through local adaptation and response to host resistance. Molecular Plant Pathology, 7 (4): 259-268 http://dx.doi.org/10.1111/j.1364-3703.2006.00336.x 
ISSN 1392-3196 / e-ISSN 2335-8947

Zemdirbyste-Agriculture, vol. 101, No. 2 (2014), p. 177-184

DOI $10.13080 / \mathrm{z}-\mathrm{a} .2014 .101 .023$

\title{
Mycosphaerella graminicola izoliatu jautrumas demetilinimo inhibitorių (DMI) grupès fungicidams
}

\author{
A. Ronis ${ }^{1}$, L. N. Jørgensen ${ }^{2}$, R. Semaškienè ${ }^{1}$, I. Gaurilčikienè ${ }^{1}$, J. Ramanauskiene் $\dot{1}^{1}$ \\ ${ }^{1}$ Lietuvos agrarinių ir miškų mokslų centro Žemdirbystès institutas \\ ${ }^{2}$ Aarhus universitetas, Danija
}

\section{Santrauka}

Grybas Mycosphaerella graminicola (Fuckel) J. Schröt. (anamorfa Zymoseptoria tritici (Desm.) Quaedvlieg \& Crous) sukelia kviečių lapų septoriozę. Dėl šios ligos kviečių derliaus nuostoliai gali siekti 30-50\%, todèl esant stipriam ligos išplitimui būtina naudoti fungicidus. İvairiose Lietuvos vietovėse buvo surinkti kviečių lapai su lapų septoriozės simptomais. Laboratorijoje iš atskirų piknidžių buvo išskirtos grynos grybo kultūros ir, taikant in vitro metodą, ištirtas jų jautrumas demetilinimo inhibitorių (DMI) grupès fungicidams epoksikonazolui, ciprokonazolui bei protiokonazolui. Fungicidų koncentracijos buvo pasirinktos pagal Atsparumo fungicidams veiksmų komiteto (FRAC) pasiūlytą metodiką. 96 duobučių mikroplokštelès buvo inokuliuotos piknidiosporų suspensija. Per trejus eksperimento vykdymo metus (2009-2011) buvo ištirti 196 izoliatai iš 34 skirtingų vietovių. Tyrimų rezultatai parodè, kad nustatytas mažejantis grybo M. graminicola izoliatų jautrumas DMI grupés fungicidams. Fungicido epoksikonazolo vidutine $\mathrm{EC}_{50}$ reikšmè buvo nuo 1,02 iki $3,15 \mathrm{mg} \mathrm{l}^{-1}$, o fungicido ciprokonazolo - nuo 1,51 iki $10,66 \mathrm{mg} \mathrm{l}^{-1}$. Ištyrus $(2011 \mathrm{~m}$.) 64 izoliatus iš 13 skirtingų vietovių nustatyta, kad fungicido protiokonazolo vidutinė $\mathrm{EC}_{50}$ reikšmė buvo nuo 0,43 iki 32,28 $\mathrm{mg} \mathrm{l}^{-1}$. Lauko tyrimų metu (2007-2011 m.) nustatyta, kad fungicidai epoksikonazolas ir protiokonazolas efektyviai sumažino žieminių kviečių lapų septoriozès AUDPC reikšmes. Daugeliu atvejų vienkartinis purškimas fungicidu esmingai padidino grūdų derlių ir tūkstančio grūdų masę.

Reikšminiai žodžiai: AUDPC, ciprokonazolas, epoksikonazolas, jautrumas, Mycosphaerella graminicola, protiokonazolas, žieminiai kviečiai. 